\title{
Analysis of the Determinants of Tax Policy Compliance in Nigeria
}

\author{
Robert Dibie, Ph.D. \\ Professor of Public Policy, Public Management and Environmental Studies \\ Department of Public Administration and Health Management \\ Indiana University Kokomo, \\ Kokomo, IN 46904 USA \\ E-mail: rdibie@yahoo.com \\ Raphael Dibie, M.Sc. Ph D Candidate \\ Department of Accounting \\ School of Business \\ University of Benin \\ Benin City, Nigeria
}

Received: March 3, 2020 Accepted: March 30, 2020 Online published: April 30, 2020

doi:10.5296/jpag.v10i2.16934 URL: https://doi.org/10.5296/jpag.v10i2.16934

\begin{abstract}
This paper examines the factors that determines tax policy compliance and the impediments to effective tax administration in Nigeria. The objectives are to: (a) determine if there is a relationship between knowledge of tax laws and compliance in Nigeria; and (b) if there is a positive relationship between corruption and tax compliance. The paper argues that taxpayers' knowledge of Nigerian tax laws could positively influence citizens attitude and behavior towards compliance. The primary data were derived from interviews, and questionnaires. The conceptual frameworks are based on strategic and benchmark approaches, and principal agent model. The data analysis shows that there is a strong positive relationship between lack of tax knowledge, low level of education and tax compliance in Nigeria. The findings of this study also reveal that there is a strong positive correlation between corruption and tax evasion. The inadequate use of information technology in tax administration, and lack of government incentives as well as poor working condition have negative correlation with tax collection
\end{abstract}


management. There is however significant relationship between inappropriate assessment system, poor economic situation in the country, and lower tax compliance rate in the country. Some benchmark strategic policy recommendations are provided on how to better implement tax compliance laws in Nigeria in the future.

Keywords: taxation, accounting, economic development, financial assessment, tax compliance, management of national income, economic growth

\section{Introduction}

Many accounting and financial management policies have been applied to boost growth and reduce poverty in several developed and developing nations around the world (Fjeldstad 2014; Lymer \& Oats 2009; Yesegat et al 2017). In Nigeria tax policies have become the most common and relevant instruments for collecting revenue (Fagbemi \& Agogun 2014; Foluso 2013; Okaura 2012; Tanzi \& Zee, 1997). One of the major goals for the adoption of tax policies in the country is to provide resources needed for the provision and distribution of public goods services to the citizens (Dibie, 2018). Despite these very important policy objectives, the rate of tax compliance of the citizens of Nigeria has been very low (African Development Bank 2011; Dibie, 2018; OECD 2012; Usman 2008). According to Schiller (2018) the capacity of a political system to sustain disincentivize self-aggrandizement behavior of political leaders has created a major concern for taxpayers.

The Federal Government of Nigeria has not been very effective in the provision of goods and services to members of its society (Dibie 2018; OECD 2012). The inequality in the distribution of income in the country creates a serious economic development problem in Nigeria (Fagbemi \& Abogun 2014). Moreover, the need to bring about a shift in the allocation of public goods and services through tax measures has not been effective either (Adekanola 1997; Agbadi 2011). Furthermore, the Federal Government of Nigeria often had more problems replacing revenue generated from low sales of petroleum product by exploiting the value added tax system (Dibie 2018; Fagbemi \& Abogun 2014; Kiabel \& Nwokah 2009).

Although some scholars have argued that adopting a direct tax system could enable citizens to pay according to their ability, this approach has not been effective in Nigeria (Kiabel \& Nwokah 2009; Okaura 2012). Despite the fact that the direct-tax system may be easier to collect, it may not ensure the desired distribution of the tax burden in Nigeria because of the problem of noncompliance in the private sectors especially the retail sector of the country (African Development Bank 2011; Bird 2012; Dibie 2018; Foluso 2013; Okaura 2012; Ola 2001; Usman 2008).

According to Bird (2012, Flores-Macias (2018), and Prichard (2015) taxation is a link that galvanize accountability between citizens and government to be more responsive in implementing policies that could alleviate inequality in any country. Bird (2012 and Prichard (2015) contend that taxation could help to create a fiscal exchange between citizens and government in respect of the quality of public good, trust, and income. This is because some Nigerian citizens avoid paying taxes as a form of protest for the lack of quality public goods 
and services (Alabede 2014; Flores-Macias 2018; Fjeldstad 2014; Jibao \& Prichard 2015; Ondetti 2015).

Tax is defined as revenue collected by the federal or state or regional governments respectively to provide goods and services equitably to all its citizens. There are many types of taxes (Fagbemi \& Abogun 2014). The most common tax system in Nigeria are payroll tax, tax on individual income, taxes on corporate income, and taxes on consumption for example sales tax or value added tax (Agbadi 2011; Fagbemi \& Abogun 2014). The federal and state governments in Nigeria collect taxes to pay expenses such as defense of the country, maintenance of law and order, imparting justice, providing welfare services, maintenance of staff and office structure or buildings, and servicing existing debt as well as ensuring economic growth through fiscal and monetary policies (Gruber 2019; Bhatia 2005). Government also need to finance its income, expenditure and capital assets, for which the taxpayers receives nothing specific in return (African Development Bank 2011; Fagbemi \& Abogun 2014; OECD 2012).

The literature on tax compliance in Africa identifies economic recession, hyperinflation, natural disaster, high unemployment, safety and security. In addition, low level of education, trust in government; equity in the distribution of goods and services, corruption as well as more structural factors tends to affect governments' ability to collect tax or enforce tax compliance (Agbadi 2011; Fagbemi \& Abogun 2014; Fjeldstad 2014; Jibao \& Prichard 2015; Ondetti 2015; Prichard 2015). Therefore, the dependence on taxes would require the Federal Government of Nigeria to develop pragmatic bureaucratic departments or agencies for tax administration as well as proactive collection systems in the country (Fjeldstad 2014; Okaura 2012; Usman 2008).

Many scholars have also contended that there is a strong positive correlation between tax collection and development (Gruber 2019; Jibao \& Prichard 2015; Fjeldstad 2014). On one hand, they argued that an effective national tax system may be paramount to the attainment of sustainable development because such payer mechanism could galvanize the domestic revenue base for developing countries (Brautigam et al 2008; Fjeldsttad 2014; OECD 2012; Moore 2008). Brautigam, Fjeldstad \& Moore (2008) also argues that there is a moderate relationship between nation building and effective taxation. This is because tax revenue could enhance governance and stronger incentives to promote economic growth (African Development Bank 2011; Moore 2008; OECD 2012).

Flores-Macias (2018) and Schneider (2012) contend that although appropriate taxation system could spill over to a nation's growth and strength as well as constructively establish a vibrant relationship between political leaders and citizens, the tax-payers bearing the burden do not really like to accept responsibility to do so. In the Nigerian situation, taxation has not led to any meaningful process of negotiation between the federal, state and local governments and the citizens that actually pay the taxes (Alabede 2014; Dibie 2018; Fjeldstad 2014). One other problem is that Nigeria citizens have not been able to develop the courage to demand accountability from their government. The capability to demand something in return for paying taxes might galvanize transparency and accountability in the country. The bone of 
contention, however is that in the past three decades the government has not been effective in using taxpayers' money to provide goods and services that could benefit all the citizens despite their income levels and state of origin (African Development Bank 2011; Alabede 2014; Foluso 2013 Moore 2008).

Direct and indirect tax is an important element in managing national income in both developed and developing countries (Flores-Macias 2018; Foluso 2013; Prichard 2015). These systems of revenue generation mechanisms have played very important roles in economic growth, infrastructure modernization and sustainable development in many African countries as well as Nigeria (Dibie 2018; Fagbemi \& Abogun 2014; Lymer \& Oats 2009; Mkandawire 2010). The problem, however, is how can the government effectively educate and communicate with the citizens in order to increase the rate of tax compliance. The current situation in the country reflects a large number of imperfections that tend to bring about defective allocation and utilization of productive resources (Fagbemi \& Abogun 2014).

One of the major problems of government revenue generation in Nigeria through taxes is the incidence of non-tax compliance by some income earners for reasons best known to them (Badara 2012; Das-Gupta 2002; Kiabel \& Okaura 2012; Ola 2001; Usman 2008). Government employees seen to be more tax compliant because their taxes are deductible directly from the source in the form of Pay as You Earn (PAYE) unlike those employees in the private sector that may manipulate their data in such a way that their tax burden becomes lower than required by law (Alabede 2014; Foluso 2013). Unfortunately, the Government of Nigeria tends to use the adversarial approach for tax collection (Fagbemi \& Abogun 2014). This approach tends to focus on "hunter and hunted" or "catch me if you can" a sequence of action that makes taxpayers and administrators to react without two-way communication (Alabede 2014; Carter \& Cebreiro 2011; Foluso 2013; Vazquez \& Bird 2011). Rather than promoting cooperation between taxpayers and tax administrators, suspicion of taxpayers often reveals detection of cheating by auditing as well as a variety of judicial and administrative measures (Braithwait, 2003; Foluso 2013; Vazquez \& Bird, 2011).

In addition, taxation can only be used to execute governments' functions efficiently where taxpayers are willing and able to comply with extant tax laws of the country (Foluso 2013; Kiabel \& Okaura 2012). However, it is widely acknowledged that most income earners do not like to pay taxes (Vazguez \& Bird 2011; Schneider, 2012), and for this reason, some income earners may fail to comply with a country's tax laws or policies. As a result of the above reasons non-tax compliance is the failure of income earner to fulfill their tax obligations either intentionally or unintentionally. The lack of commitment to their constitutional obligation by not filing tax returns, misreporting taxable income or specifying allowable deduction from taxable income or tax due, such as exemptions, tax credit and so on (Fjeldstad \& Moore, 2001; Mahon 2012).

What is missing in the tax compliance literature in Nigeria is the gap between methods of solving the impediments of lack of compliance, and appropriate actions that are needed to improve tax management and administration in the country. This paper provides an appropriate benchmark model that the Government of Nigeria and other African countries 
facing similar predicaments could adopt to prevent tax evasion (Fagbemi \& Abogun 2014; Agbadi 2011). It prescribes that future tax compliance benchmarks should include different social and economic conditions in Nigeria. The use of information technology and the provision of regular electricity in rural and urban regions of Nigeria is recommended. These sustainable development goals call for a well-suited study on how government could effectively implement fiscal and monetary policies in ways that could reduce poverty and inequality in Nigeria. One of the goals of this paper is to go beyond the current literature on tax compliance policies.

This paper investigates the factors that determines tax policy compliance and the impediments to effective tax administration in Nigeria. The objectives are to: (a) determine if there is a relationship between knowledge of tax laws and compliance in Nigeria; and (b) if there is a positive relationship between corruption and tax compliance. The paper argues that taxpayers' knowledge of Nigerian tax laws could positively influence citizens attitude and behavior towards compliance. The primary data were derived from interviews, and questionnaires. The conceptual frameworks are based on strategic and benchmark approaches, and principal agent model. The data analysis shows that there is a strong positive relationship between lack of tax knowledge, low level of education and tax compliance in Nigeria. The findings of this study also reveal that there is a strong positive correlation between corruption and tax evasion. The inadequate use of information technology in tax administration, and lack of government incentives as well as poor working condition have negative correlation with tax collection management. There is however significant relationship between inappropriate assessment system, poor economic situation in the country, and lower tax compliance rate in the country. Some benchmark strategic policy recommendations are provided on how to better implement tax compliance laws in Nigeria in the future.

\section{Conceptual Framework for Tax Compliance}

In many countries there are different types of taxes which can be classified into four broad categories: (1) tax on corporate income; (2) individual income tax; (3) taxes on consumption; and (4) taxes on wealth (Alabede 2014; Florces-Macias 2018; Prichard 2015). Most governments including the Federal and State governments of Nigeria depends heavily on individual income taxes. Many other countries in Africa receive much of their tax revenue from consumption taxes such as VAT (Valued added tax) (African Development Bank 2011; Foluso 2013; OECD 2012). Unfortunately, as a result of corruption, the Nigerian government do not generate much revenue from wealth (Dibie, 2018; Fagbemi \& Agbogun 2014; Adekanola 1997). Schneider (2012) contends that every economy has some form of direct and indirect tax system. In addition, the type of tax system decided by a national government depends on the composition of the nation's fiscal and monetary policies. Furthermore, reducing inequalities may have alternative effects on productions and economic growth in any country (Jibao \& Prichard 2015; Schiller 2018). The incidence of tax evasion may galvanize reduction in inequality and the ineffectiveness of a tax system (African Development Bank 2011; Bhatia 2009; Lymer \& Oats 2009).

In a democratic system of government, the citizens elect political leader to represent them in 
the administration of the affairs of the country. In such arrangement the citizens become the principal while the political leaders are classified as the agent. The principal-agent models were propounded by Jansen and Meckling (1976). The model explains that policies could be most faithfully implemented when implementation is easy to monitor. Seijan (2014) and Weingast (1984) contend that information is the most important mechanism to modify agent's behavior. This is because if the principal gets that right information, he or she could anticipate the reaction of the agent at any time (Bohren, 1998). In respect of tax compliance, if information monitoring warrants coordination, taxpayers will not have a private incentive to expand resources to ensure compliance.

The principal-agent model does not necessarily describe the principles that most political leaders should follow (Groenendijk 1997; Jansen \& Meckling 1976). Advocates of representative democracy believe that political leaders (especially in developing countries) rarely put the interest of the citizens above their own (Bohren 1998; Corgnet et al 2018; Quinn \& Jones 1995). However, the duty of a political leader is to honor his or her contract with the citizens by working diligently to provide justification for all initiatives and actions on behalf of the principal. Therefore, the moral obligation of the political leader (agent) to the citizen (principal) that elected him or her is similar to that of social contract. From a theoretical standpoint the principal-agent model requires a moral political leader to seek greater tax revenue not through higher tax rates, but through expansion of taxable economic activities (Fjeldstad 2014). This new moral tax initiative could lead to a better relationship and trust between the principal (citizens) and the political leaders (agent). According to Fjeldstad \& Moore, 2008), developing countries have been advised to desist from using taxation to try to mobilize saving or transfer resources from agriculture to non-agriculture sectors. This is because it is better to rely less on revenue from easily taxable imports, and export and place less emphasis on using higher marginal tax rates in the effort to reduce income as well as inequality among citizens (Stewart 2003; Bird 2012; Prichard 2015). Figure 1 shows the dynamic of taxation and citizens as well as public administrators or policy makers in Nigeria. 


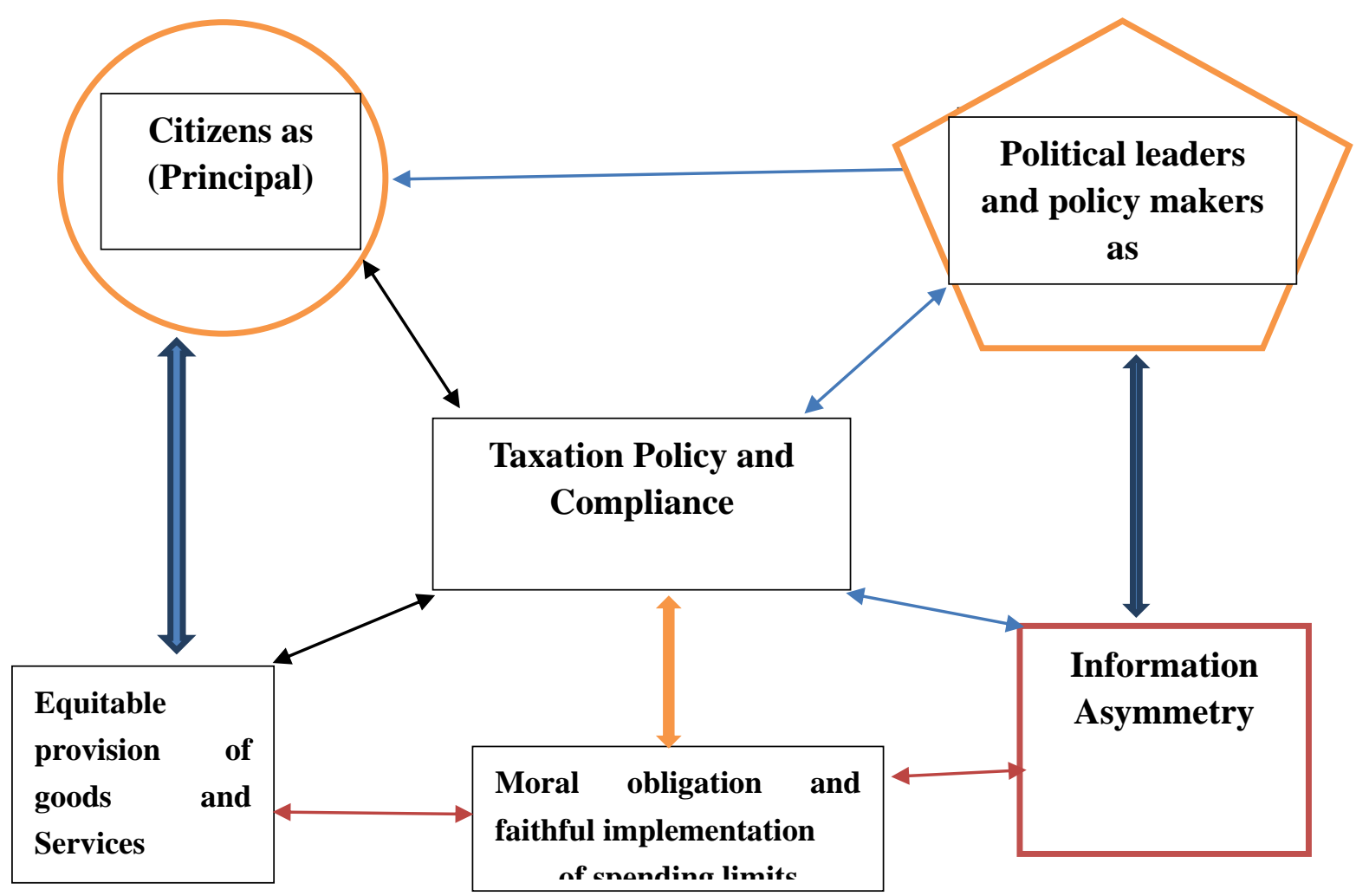

Figure 1. The Dynamics of Taxation and Citizens/Public Leaders Relations

Source: Designed by Robert. Dibie, 2020

Figure 1 shows the dynamics between taxation and policy makers in facilitating tax compliance. A tax system in any country should facilitate a better relationship between the government administrators (agent) and the citizens (principal). This relationship could also galvanize accountability between citizens and political leaders as well as make government to be more responsive in implementing policies that could alleviate inequality in any country. The figure also shows that the relationship between taxpayer and the government could create a major principal-agent predicament. This is because of the citizens' perception of the quality of public good, services and income derived. These predicaments could also result to minimal compliance. Thus, low trust in government by the citizens or taxpayers could lead to lower income generation through tax.

Furthermore, Fjeldstad and Moore (2008) and Fjeldstad (2014) contend that governments in developing countries typically does not have the administrative capacity to successfully transition to a more strategic and pragmatic revenue generating tax system. In addition, some scholars argued that one of the reasons for the failure of individual income taxation reflect both political leadership and public administration ineffectiveness as well as moral obligation to fulfil the interest of the citizens (Alabede 2014; Fagbemi \& Abogun 2014). Against this argument, political leaders are encouraged to improve tax policies and create more effective tax administration that could better serve the citizens of Nigeria. Thus, the principal-agent model predicts that policies could be most effectively implemented when agents (political 
leaders) and public administrators are monitored or held accountable. According to Seljan, (2014) if monitoring requires coordination, taxpayers will not have the incentive to expand resources to ensure compliance in any country. This assumption also leads to another set of problems whereby there might be ineffective or lack of fiscal bargaining and negotiation between the government and citizens. Thus, when such condition persists for a long-time taxation and national economic development or growth cannot take place in the country. To solve the principal-agent problem in Nigeria, the National and State legislatures will have to adopt an oversight policy to effective monitor the Federal Inland Revenue Office and tax administrators.

According to Lieberman (2003, Mkandawire (2010), and Schiller (2018) the political perspective of tax compliance and performance critically affects the socio-political patterns in any country. Lieberman (2003) contends that the pattern of interaction between the nation government of a country and the citizens that belong to the middle economic class is a vital factor in understanding the nature and difference between an adversarial and a cooperative tax system. These arguments support the premise that the political support of citizens is critical for both the adoption and sustainability of economic reform of tax administration in Nigeria. The Federal Government of Nigeria currently constitutes a weak state (Dibie 2018). The nature of the nation's weak state statues translates into administrative deficiencies in the administration and collection of taxes as well as the ability to equitably provide public goods and services for all its citizens (Dibie 2018; Flores-Macias 2018). As a result of these tax administration impediments the support of the citizens could be paramount for the political and administrative realization of both economic transformation and tax compliance in the future.

The benchmark approach and strategic practices has been recommended as one of the best methods for evaluating the performance of tax administration (Das-Gupta 2002; Bird \& Banta 2000). According to Vazquez-Catro and Bird (2011) benchmarking is an effective way of establishing a timetable for tax compliance. The approach helps to set a clear and ideally measurable objective to determine tax compliance outcomes. The benchmark approach requires the setting of appropriate performance measure that strategically spell out the objectives that are expected (Vazquez-Castro \& Bird 2011). The benchmark approach is also referred to as the cooperative compliance model because it focuses not only on expanding tax collection but ensure that citizens' pay their fair share of taxes. According to Baer, Benon and Toro (2001) cooperative compliance also facilitates customer and client orientation because of the possibility of developing taxpayer segmentation as well as organizational strategy for targeting different citizen groups. Cooperative compliance also facilitates good risk analysis and a better understanding of the taxpayers' population, i.e. low, middle and higher-income groups, retailers, public sector employees, wholesalers, manufacturers, types of business and so on. It is also a system that could help tax administrators to create an in-depth analysis method in order to understand the multiple access channels and services for tax advisors (Vazquez-Catro and Bird 2011; Pinhanez 2008). The gathering and understanding the nature of the activities of the citizens that pay tax in a country is paramount to a successful tax administration approach. Figure 2 shows a model of the impediments to tax administration 
and how benchmark and strategic approaches could be used to resolve the lack of compliance problems in Nigeria.

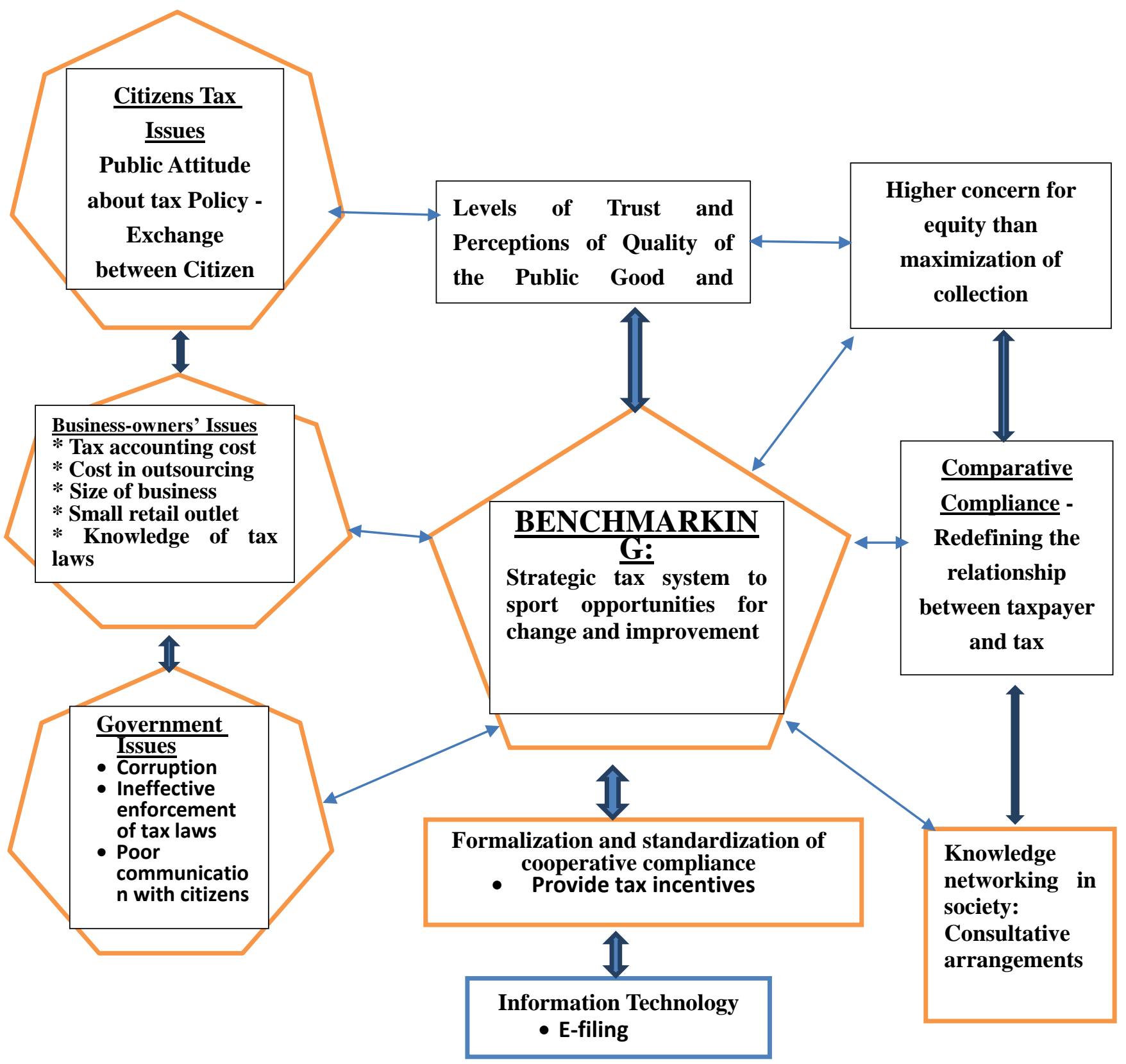

Figure 2. Model of the Dynamics of Factors that affects Tax Compliance and Solutions

Source: Designed by Robert Dibie, 2020

Figure 2 shows the impediments to tax compliance in three major areas (individual citizens. Business owners and government. As a result of government ineffective delivery of goods and services, the citizens and business owners do not trust the government. Higher concern for inequality and corruption has also galvanized the inability of government to maximize economic development in the country. Majority of the most successful benchmark approach has been carried out by tax administrators of affected nations because they appreciate the 
direct benefit of reporting accurate and critical data that could result in the transformation of tax compliance in their home country (Vazquez-Catro et al 1992).

The possible solutions to the lack of tax compliance problem in Nigeria may be the adoption of a new strategic benchmark tax system. The benchmark approach requires the government to establish a formal relationship with citizens as well as adopting a standardized cooperative compliance method that could help to produce positive outcomes. It also calls for the provision of tax incentives as well as the use of information technology to facilitate e-filing, resource sharing with citizens, and better communication. One of the short comings of the benchmark approach to tax administration is that whenever the model is executed or implemented by foreign tax experts that are recruited outside a nation's government it is likely not to be successful (Vazquez-Catro et al 1992).

The concepts and theories discussed in this paper all collaborated the need to be a positive relationship between tax payed by citizens and the amount of public goods and services received by taxpayers. The review of literature on taxation also reveals that citizens trust in government is paramount to individuals, business owners support, and tax compliance policy. One of the major arguments presented in this paper is that proactive tax administration reforms, pragmatic benchmarks and considerable as well as sustained initiatives are required before tax administration, sustainable development and nation-building goals could be attained in Nigeria (Dibie 2018; Jibao \& Prichard 2015). In addition, the citizens of Nigeria may have to consider new tax administration initiatives as legitimate before voluntary tax compliance will take place in the country.

\section{Research Method}

The purpose of this paper is to investigate the factors that determines tax policy compliance and impediments to effective tax administration in Nigeria. A total of 5,000 questionnaire were administered to citizens of Nigeria. The participants of the study included many tax administrators working for the federal, and state governments, private sole corporations staff, partnership corporation staff, retail outlet owners, non-governmental organizations (NGOs) staff, suppliers and distributors, clerical officers, treasurer of civil society groups, law enforcement officers in companies, stakeholders such as vendors, senior administrators of oil companies, taxi drivers, lawyers, youth corps service members, political leaders, local community' organizations' members, engineers, suppliers and distributors to retail outlets, and shop owners. The participants were residents of Abuja the national capital and the following states in Nigeria Lagos, Ogun, Oyo, Kwara, Edo Delta, Rivers, Akwa-Ibom, Bayesa, Imo, Anambra, Ekiti, Ebonyi, Kongi, and Enugu states).

The secondary data consists of the review of related government reports in Nigeria, academic and professional journals. The research was conducted between 2018 and 2019 in Nigeria. A total of 3,800 (76\%) questionnaires were completed and returned by the respondents. Four hundred (400) in-depth interviews were also conducted. The participants of the interviews include the same sample of respondents like those of the questionnaire. Data collected were analyzed with SPSS statistical tool and presented in correlations, tables and percentile. 
The central research questions are: (1) What do you think are the impediments to individual citizen's tax compliance in Nigeria? (2) Why are some business owners not paying taxes in Nigeria? and (3) Do you believe that the Federal and State Governments in Nigeria are effective in the administration of tax compliance in the country?

The limitation of the study is that only states in southern and middle region of Nigeria were covered by this research. Despite the limitation of the study, the northern and southern states tend have similar tax compliance impediments. Federal, states, and local governments' employees were not covered in this study because their taxes are deductible in the form of "Pay as You Earn (PAYE) progressive system" unlike those employees in some private sector. In addition, most of the state governments share almost the same characteristics except for a few that are located in rural regions and lack electricity. The dependent variable is tax compliance, and the independent variables are tax individual tax compliance impediments, business owners tax impediments and government tax administration impediments.

\section{Analysis of Data and Discussion}

Demographic characteristics of the 3,800 respondents that returned the completed questionnaires reveal that $56 \%$ were male, while $44 \%$ were female. About $38 \%$ were in the age range of 45-65 years old. While $34 \%$ were between $25-45$ years old. The youngest group were $28 \%$ and between 19-24 years of age. The survey data also reveals that $5 \%$ of the respondents hold a doctoral degree. Another 17\% earned a master's degree. Further $34 \%$ of the respondents have a bachelor (BA or BSc or HND) degree or diploma from a university or polytechnic higher education institution. In addition, $20 \%$ of the respondents have either ordinary national diploma (OND) or high school certificate. The remaining $24 \%$ of the respondents are uneducated or did not complete high school education. The implication of these demographic characteristics of the respondents is that $44 \%$ of surveyed respondents do not know or are not aware of the tax policies in Nigeria. While almost $35 \%$ of the respondents with BS, BA or HND are currently unemployed and do not pay income tax. The remaining $21 \%$ live in rural regions where tax policies are not effectively enforced.

The questionnaire was divided into three sections: (1) individuals, (2) small business owners, and (3) federal and state governments tax administrators. One thousand, three hundred and twenty $(1,320)$ respondents in the private sector provided response to the first section. Another 1,400 small business owners also completed the questionnaire. The third section of the questionnaire was completed by 1,080 tax administrators at both the federal and several state governments respectively.

The 400 in-depth one on one interviews were also conducted with respondents from the three sectors stated above: (1) individuals 130 respondents; (2) small business owners 150 respondents; and (3) federal and state governments 'tax administrators 120 respondents. Some of the comments of these interview respondents are provided below each of the three research questionnaire tables. As stated previously in this paper, federal and state governments staff where not including in the study of (1) individuals; (2) small business owners because they already pay their taxes through the PAYE system. 


\section{Macrothink}

Table 1 shows the major reasons why individual respondents failed to comply with Nigeria's governments tax laws. Among the 1,320 participants that responded to the individual section of the questionnaire $88.4 \%$ indicated that they fail to comply because of the poor economic situation in the country. As a result of the non-caring attitude of the tax administrators and political leaders in the country $81 \%$ of the respondents stated that they do not trust the government of Nigeria because of the way it is handling the economy as well as the inadequate distribution of goods and services in the country. In addition, $81 \%$ of the respondents indicated that the reason why they do not comply with the tax laws in the country is because they are not satisfied with the inadequate goods and services provided by both the federal and state governments in Nigeria. Further, $79.5 \%$ of the respondents stated that they do not comply with tax laws because of inequitable distribution of goods and services in the country. Eighty-five percent (85\%) reported that they do not trust tax administrators in Nigeria.

In addition, table 1 also shows that $79 \%$ of the respondents indicated that they do not pay taxes because they are either not employed or they are concerned with the high rate of unemployment among university graduates in the country. Eighty-nine percent (89\%) indicated that due to arbitrary corruption by both political leaders and senior public administrators they do not wish to comply with tax laws in the country. On one hand, $88.4 \%$ questionnaire respondents reported that they do not pay taxes due to the bad economic situation in Nigeria. On the other hand, $79.4 \%$ of the respondents indicated that because of lack of constructive government and citizen relationship or engagement in Nigeria they do not feel compel to comply with tax policies. The mean of table 1 data is: Agree $81.5 \%$ and Disagree $17.1 \%$ respectively.

Research Question 1: What do you think are the impediments to individual citizen's tax compliance in Nigeria?

Table 1. Why Individual Citizens Fail to Pay Taxes

\begin{tabular}{|c|c|c|c|c|c|c|c|c|c|}
\hline No & Questions & $\begin{array}{c}\text { \# of } \\
\text { Strongly } \\
\text { Disagree }\end{array}$ & $\begin{array}{c}\text { \# of } \\
\text { Disagree }\end{array}$ & $\begin{array}{c}\text { \# of } \\
\text { Neutral }\end{array}$ & $\begin{array}{c}\text { \# of } \\
\text { Strongly } \\
\text { Agree }\end{array}$ & $\begin{array}{c}\text { \# of } \\
\text { Agree }\end{array}$ & $\begin{array}{c}\% \text { of } \\
\text { Disagree }\end{array}$ & $\begin{array}{c}\% \\
\text { Agree }\end{array}$ & $\begin{array}{l}\text { Total } \\
1,320\end{array}$ \\
\hline 8 & $\begin{array}{l}\text { Fail to pay tax because of } \\
\text { inequitable distribution of } \\
\text { goods and services in the } \\
\text { country }\end{array}$ & 52 & 200 & 18 & 460 & 590 & $\begin{array}{l}252 \\
19 \%\end{array}$ & $\begin{array}{c}1050 \\
79.5 \% *\end{array}$ & 1320 \\
\hline 9 & High unemployment rate & 43 & 212 & 21 & 433 & 611 & $\begin{array}{c}255 \\
19.3 \%\end{array}$ & $\begin{array}{c}1044 \\
79 \% *\end{array}$ & 1320 \\
\hline 10 & $\begin{array}{l}\text { Poor constructive } \\
\text { government and citizen } \\
\text { engagement }\end{array}$ & 113 & 144 & 15 & 298 & 750 & $\begin{array}{c}257 \\
19.5 \%\end{array}$ & $\begin{array}{c}1048 \\
79.4 \%\end{array}$ & \\
\hline 11 & Lack of trust in government & 102 & 140 & 9 & 142 & 927 & $\begin{array}{c}242 \\
18.3 \%\end{array}$ & $\begin{array}{l}1069 \\
81 \%\end{array}$ & 1320 \\
\hline
\end{tabular}




\begin{tabular}{|c|c|c|c|c|c|c|c|c|c|}
\hline 12 & $\begin{array}{l}\text { Not satisfied with the } \\
\text { inadequate goods and } \\
\text { services provided by } \\
\text { governments }\end{array}$ & 92 & 100 & 17 & 223 & 888 & 192 & 1111 & 1320 \\
\hline 13 & $\begin{array}{l}\text { Do not have trust in tax } \\
\text { administrators }\end{array}$ & 61 & 116 & 23 & 218 & 902 & $\begin{array}{c}177 \\
13.4 \%\end{array}$ & $\begin{array}{l}1120 \\
85 \% *\end{array}$ & 1320 \\
\hline 14 & $\begin{array}{l}\text { Arbitrary corruption by } \\
\text { both political leaders and } \\
\text { senior public administrators }\end{array}$ & 58 & 90 & 0 & 207 & 965 & 148 & $\begin{array}{l}1172 \\
89 \%\end{array}$ & 1320 \\
\hline 15 & $\begin{array}{l}\text { Government fail to provide } \\
\text { adequate safety }\end{array}$ & 77 & 120 & 9 & 411 & 703 & $\begin{array}{l}197 \\
15 \%\end{array}$ & $\begin{array}{c}1114 \\
84.4 \% *\end{array}$ & 1320 \\
\hline 16 & $\begin{array}{l}\text { My low level of education } \\
\text { and knowledge of tax } \\
\text { policy }\end{array}$ & 118 & 320 & 15 & 402 & 465 & $\begin{array}{c}438 \\
33.2 \%\end{array}$ & $\begin{array}{c}867 \\
65.7 \%\end{array}$ & 1320 \\
\hline 17 & $\begin{array}{l}\text { Poor economy situation in } \\
\text { the country }\end{array}$ & 47 & 50 & 3 & 229 & 938 & $\begin{array}{c}97 \\
7.3 \%\end{array}$ & $\begin{array}{c}1167 \\
88.4 \% *\end{array}$ & 1320 \\
\hline & Mean & & & & & & $17.1 \%$ & $81.5 \%$ & \\
\hline
\end{tabular}

Source: Derived from field research in Nigeria in 2018 and 2019.

Furthermore, $63 \%$ of the individual interview respondents indicated that they fail to pay taxes because they cannot see what the government might be doing with the citizens' money that they collect as taxes. Another 34\% of the interview respondents from this sector stated that one of the reasons why they do not pay taxes is because they believe that the federal and state governments officials do not care about the welfare of the citizens. It is because the elected government officials and public administrators do not care about the citizens that is why there is a weak constructive citizens and government relations all over the country. Another, 94\% of the individuals interview respondents indicated that rather than Nigerian political leaders to use tax payers money to provide goods and services for every citizens to benefit or enjoy they would take the nation's money to Europe or United States to enjoy with their family members while the poor people in the country suffers. Fifty eighty percent $(58 \%)$ of the individual group interview respondents stated that they were not aware of some of the federal and state governments' tax laws in Nigeria.

Forty-nine percent (49\%) of the respondents living in rural communities and are farmers stated that they have not paid taxes in their entire life. When the individual, respondents interviewed were asked about their perception of tax laws in Nigeria, 59\% indicated that it is very bad. Another $22 \%$ stated that it fair but it will require a lot of study time in order to attain better understanding. The remaining $29 \%$ indicated that because they are currently unemployed it would not be fair to rate the tax laws of the country. However, there is a consensus among the citizens that the federal and state governments in the country are not using the money collected from taxes to provide goods and services that all citizen in the country. This statement is obvious because of the lack of constant electricity supply, poor health system, bad roads, dilapidated primary and high school buildings as well as ineffective strategies for economic development that could have created more jobs and reduce 
unemployment. Below are some the statements made by the interview respondents.

"Why should I pay taxes to the government of Nigeria while I provide my own electricity and water. The government of Nigeria has made all the citizens to become local governments by making us to be very individualistic in providing goods and services for ourselves. It is really a shame and sad."

"In those days when political leaders and senior public administrators send their children to public schools in Nigeria, tax money were properly distributed to provide good schools and healthcare. However, now adays they send their children and family member to London and the United States and allow our public schools to be run down. May God help us"

"Corruption among Nigerian political leaders and senior public administrators has no doubt contributed to the ineffective utilization of tax revenue to address the needs of the citizens".

"I am a poor farmer why should I be asked to pay tax."

"The government does not feed me, despite the fact that I do not have a job, so why should I pay tax." Please do not bother me with tax issues." Nigeria is not the government for the people and by the people."

Correlation coefficient

$$
\begin{aligned}
& \mathrm{r}={ }^{\mathrm{n}}\left(\Sigma^{\mathrm{xy}}\right)-\left(\Sigma^{\mathrm{x}}\right)\left(\Sigma^{\mathrm{y}}\right) \\
& \sqrt{\left[{ }^{\mathrm{n}}\left(\Sigma_{\mathrm{X}}{ }^{2}\right)-\left(\Sigma^{\mathrm{x}}\right)^{2}\right]\left[{ } ^ { \mathrm { n } } \left({\underline{\underline{\Sigma^{\mathrm{y}}}}}^{2}-\left({\underline{\Sigma^{\mathrm{y}}}}^{2}\right]\right.\right.}
\end{aligned}
$$

Table 2. Correlation Matrix for Individual Tax compliance

\begin{tabular}{|l|l|c|c|}
\hline Tax Compliance Factors & Index & $\begin{array}{l}\text { Average } \\
\text { Agree } \\
\text { Factors in \% }\end{array}$ & $\begin{array}{l}\text { Average } \\
\text { Disagree } \\
\text { Factors in \% }\end{array}$ \\
\hline Tax Policy Index & 0.105 & $81 \%$ & $17.1 \%$ \\
\hline Poor economy situation in the country & $0.117^{* *}$ & $88.4 \%$ & $7.3 \%$ \\
\hline $\begin{array}{l}\text { Not satisfied with the inadequate goods and } \\
\text { services provided by governments }\end{array}$ & $0.105^{* *}$ & $81 \%$ & $15 \%$ \\
\hline $\begin{array}{l}\text { Arbitrary corruption by both political leaders } \\
\text { and tax administrators }\end{array}$ & $0.116^{* *}$ & $88 \%$ & $11 \%$ \\
\hline High unemployment rate & $0.095^{*}$ & $79 \%$ & $19.3 \%$ \\
\hline My low level of education & $0.076^{*}$ & $65.7 \%$ & $33.2 \%$ \\
\hline Do not have trust in government & $0.114^{* *}$ & $85 \%$ & $13.4 \%$ \\
\hline
\end{tabular}

* Correlation is significant at the 0.05 level (2-tailed)

Table 2 shows the correlation matrix for tax compliance in Nigeria. The table also shows a 
very strong positive correlation of $(0.117)$ between non-tax compliance and poor economic situation in Nigeria. There is also a positive correlation between non-tax compliance and corruption by political leaders and tax administrators (0.116) in the country. Further, while there is a strong correlation between non-tax compliance and low trust in government (0.114), the relationship between non-tax compliance and low level of education is positive $(0.124)$ but not as high. In addition, on one hand, there is a positive correlation between non-tax compliance and high unemployment rate (0.095), and on the other hand, there is also a positive relationship between citizens not satisfy with the inadequate good and services provided by the government and non-tax compliance (0.105) in Nigeria. In addition, there is a moderate positive correction (0.076) between low level of education and non-tax compliance by the citizens. The negative non-tax compliance is significant in all the factors that were examined by the questionnaire. The findings in respect of citizens trust in government and non-tax compliance is consistent with the research previously conducted by Fjeldstad (2014) that concluded that a fair taxation system could help to build trust between government and citizens. In addition, the strong positive correction between tax evasion and corruption results is also consistent with the findings of Coolidge (2012) research in other developing countries. The data analysis confirms the major reasons why individuals in Nigeria do not comply with the tax laws of the country.

Research Question 2: Why are some business owners not paying taxes in Nigeria?

Table 3. Why some Business Owners not Paying Taxes

\begin{tabular}{|c|c|c|c|c|c|c|c|c|c|}
\hline No & Questions & $\begin{array}{c}\text { \# of } \\
\text { Strongly } \\
\text { Disagree }\end{array}$ & $\begin{array}{c}\text { \# of } \\
\text { Disagree }\end{array}$ & $\begin{array}{c}\# \text { of } \\
\text { Neutral }\end{array}$ & $\begin{array}{c}\text { \# of } \\
\text { Strongly } \\
\text { Agree }\end{array}$ & $\begin{array}{c}\text { \# of } \\
\text { Agree }\end{array}$ & $\begin{array}{c}\% \text { of } \\
\text { Disagree }\end{array}$ & $\begin{array}{c}\% \\
\text { Agree }\end{array}$ & $\begin{array}{l}\text { Total } \\
1,400\end{array}$ \\
\hline 18 & $\begin{array}{l}\text { Fail to pay tax because of } \\
\text { difficulty in bookkeeping or } \\
\text { poor record of revenue and } \\
\text { expenditure cost }\end{array}$ & 94 & 260 & 90 & 560 & 406 & $\begin{array}{c}354 \\
25.3 \%\end{array}$ & $\begin{array}{l}966 \\
69 \%\end{array}$ & 1,400 \\
\hline 19 & $\begin{array}{l}\text { Do not use cash machine. } \\
\text { to monitor sales }\end{array}$ & 0 & 0 & 0 & 930 & 470 & $\begin{array}{c}0 \\
0 \%\end{array}$ & $\begin{array}{c}1400 \\
100 \% *\end{array}$ & 1,400 \\
\hline 20 & $\begin{array}{l}\text { Not aware of tax laws in } \\
\text { the country }\end{array}$ & 312 & 100 & 8 & 580 & 400 & $\begin{array}{c}412 \\
29.4 \%\end{array}$ & $\begin{array}{c}980 \\
70 \% *\end{array}$ & 1,400 \\
\hline 21 & Small size of business & 230 & 209 & 41 & 249 & 671 & $\begin{array}{c}439 \\
31.4 \%\end{array}$ & $\begin{array}{l}920 \\
66 \%\end{array}$ & 1,400 \\
\hline 22 & High tax compliance cost & 150 & 166 & 14 & 500 & 570 & $\begin{array}{l}316 \\
23 \%\end{array}$ & $\begin{array}{c}1070 \\
76.4 \% *\end{array}$ & 1,400 \\
\hline 23 & $\begin{array}{l}\text { Corruption by tax } \\
\text { administrators }\end{array}$ & 150 & 266 & 10 & 376 & 598 & $\begin{array}{l}416 \\
30 \%\end{array}$ & $\begin{array}{c}974 \\
69.6 \% *\end{array}$ & 1,400 \\
\hline 24 & $\begin{array}{l}\text { Business owners' low profit } \\
\text { margin }\end{array}$ & 545 & 618 & 7 & 114 & 116 & $\begin{array}{l}1163 \\
83 \% *\end{array}$ & $\begin{array}{c}230 \\
16.4 \%\end{array}$ & 1,400 \\
\hline 25 & $\begin{array}{l}\text { Low education level of } \\
\text { small business owners. }\end{array}$ & 480 & 556 & 15 & 141 & 208 & $\begin{array}{l}1036 \\
74 \%\end{array}$ & $\begin{array}{l}349 \\
25 \%\end{array}$ & 1,400 \\
\hline
\end{tabular}




\begin{tabular}{|c|c|c|c|c|c|c|c|c|c|}
\hline 26 & $\begin{array}{l}\text { High cost of outsourcing tax } \\
\text { work or cost of in-house } \\
\text { time on tax accounting }\end{array}$ & 204 & 302 & 22 & 388 & 462 & $\begin{array}{l}506 \\
36 \%\end{array}$ & $\begin{array}{l}850 \\
61 \%\end{array}$ & 1,400 \\
\hline 27 & $\begin{array}{l}\text { No accurate measure of } \\
\text { annual profit and loss }\end{array}$ & 80 & 155 & 33 & 467 & 675 & $\begin{array}{c}235 \\
16.8 \%\end{array}$ & $\begin{array}{l}1142 \\
82 \% *\end{array}$ & 1,400 \\
\hline 28 & $\begin{array}{l}\text { Rural location of business } \\
\text { and no tax office nearby }\end{array}$ & 7 & 121 & 3 & 343 & 926 & $\begin{array}{l}128 \\
9 \%\end{array}$ & $\begin{array}{l}1269 \\
91 \% *\end{array}$ & 1,400 \\
\hline & Mean & & & & & & $32.5 \%$ & $66 \%$ & \\
\hline
\end{tabular}

Source: Derived from field research in Nigeria in 2018 and 2019.

Table 3 shows the major reasons why small business owner respondents failed to comply with Nigeria's governments tax laws. Among the 1,400 small business owners that responded to the questionnaire $100 \%$ indicated that they do not use cash machine to monitor their business transaction or sales. As a result of this major impediments they are unable to accurately calculate the profit and lost as well as the required percentage tax to pay each year.

Another $91 \%$ of the small business owner stated that because they operate in rural areas where there are no tax offices nearby or where tax administrators do not check their activities, they have not been complying with the tax laws in Nigeria. In addition, $82 \%$ of the small business owners in cities and rural areas reported that they do not pay taxes because of the inability (poor bookkeeping skills) to accurately measure their annual expenses and profit. During our field research we also observed that almost all the small business stores and their staff do not have computers nor internet connection. Another set of $76.4 \%$ of the small business owners' respondents indicated that previous high outsourcing tax compliance cost has discouraged them from paying their taxes. These set of small business owners argued that the mixture of in-house tax work and out-sourced tax compliance was becoming too expensive for them to pay. While $70 \%$ of the small business respondents reported that they were not aware of the tax laws in Nigeria, the same group $70 \%$ of the respondents also stated that corruption by tax administrators constitute why they do not wish to pay taxes. In addition, $83 \%$ of the small business owners' respondents disagree that business low profit is not an excuse for non-tax compliance. Further, $74 \%$ of the respondents acknowledge that low education level of small business owners is not a legitimate excuse for not complying with the tax laws of the country. Eighty three percent $(83 \%)$ of the small business owners that respondents stated that although evasion of tax compliance is not an excuse, low profit margin is the reason for non-compliance. The mean of table 3 data is: Agree $66 \%$ and Disagree $32.5 \%$ respectively.

Among the 150 small business owners that were interviewed 57\% indicated that it was cheaper to pay tax inspector some bribe than to spend money on outsourcing all their business bookkeeping. They acknowledge that many tax administrators are more interested in negotiating with small business owners to reduce their tax payment in return for courtesy gift or bribe. To compound the above problem, $72 \%$ percent of the respondents that they were not aware that they are legally required to register their business with the in-land revenue tax office in Nigeria. Another $45 \%$ indicated that they do know that the law requires them to have 
a business license. It was also mind blogging that $38 \%$ of the small business owners (mostly retail shop owners) stated that they were not aware that they had to pay taxes to the government, as well as deduct payroll taxes from their staff salary.

In addition, while $27 \%$ of the respondents indicated that tax compliance issues are very difficult to handle due to the very small nature of their volatile business operations. Nineteen percent (19\%) also reported that the fear of aggressive tax administrators who are not interested in negotiating bribe as well as weak enforcement of the law has made them to have mixed feeling whether to comply or not. When the small business owners, respondents interviewed were asked about their perception of tax laws in Nigeria, $88 \%$ indicated that it is very bad. This is because they struggle to understand the provisions of the tax form or how to calculate percentages. It should be noted that more than $65 \%$ of the small retail business owners in Nigeria completed only primary or secondary education. Seventy-one percent (71\%) also stated that they do not keep physical receipts of merchandise purchase from whole sellers or big corporations. Another $63 \%$ of the respondents interviewed wonder why the federal and state governments in Nigeria are not using revenue derived from taxes on petroleum to provide public safety, electricity, health care and good education for all citizens in the country. Below are some of the statements made by the interview respondents.

"Since no government tax inspectors or administrators have never come to bother me, why should I go to their office to report myself or spend my hard-earned money to pay tax."

"I would like to pay some taxes however the nature of my small retail business makes it very difficult to assess my profit."

"Fear of inspectors and audit is what has made me to out-source my business tax problem to the experts to help me figure out what I need to pay every year."

"Corruption associated with tax administrators or inspectors and their desire to achieve revenue target or extract bribe is a major impediment to tax collection in Nigeria."

"Paying bribe to avoid tax inspectors' repressive consequences is why we have to waste hard earned money to pay taxes."

"I pay taxes because I do not want my business to be disrupted due to punishment for non-compliance."

"Business tax compliance is a good thing for Nigeria's economic development however, the government is not doing a good job in effectively communicating the tax laws to business owners."

"From experience I believe that very high tax compliance cost has made many of 
my business friends not to comply with the payment of taxes for their staff and company.

Table 3 shows a strong positive correlation of (0.260) for not using cash machine to monitor sales, and non-tax compliance. There is also a strong positive correlation between no accurate measure of annual profit and loss (0.087), and non-tax compliance. The impediment of rural location of small business and no tax office nearby (0.175) reflects a positive relationship with non-tax compliance as well. Further, the small size of business has a strong positive correlation (0.058) with the non-tax compliance in Nigeria.

Table 4. Correlation Matrix for Individual Tax compliance

\begin{tabular}{|l|l|l|c|}
\hline Tax Compliance Factors & Index & $\begin{array}{l}\text { Average } \\
\text { Agree } \\
\text { Factors } \\
\text { in \% }\end{array}$ & $\begin{array}{l}\text { Average } \\
\text { Disagree } \\
\text { Factors } \\
\text { in \% }\end{array}$ \\
\hline Tax Policy Index & $0.058^{*}$ & $66 \%$ & $32 \%$ \\
\hline Do not use cash machine to monitor sales & $0.260^{* *}$ & $100 \%$ & $0 \%$ \\
\hline No accurate measure of annual profit and loss & $0.087^{*}$ & $82 \%$ & $16.8 \%$ \\
\hline Small size of business & $0.058^{*}$ & $66 \%$ & $31.4 \%$ \\
\hline Rural location of business and no tax office nearby & $0.175^{* *}$ & $91 \%$ & $9 \%$ \\
\hline Business owners' low profit margin & 0.024 & $16.4 \%$ & $83 \%$ \\
\hline Low education level of small business owners. & 0.026 & $25 \%$ & $74 \%$ \\
\hline $\begin{array}{l}\text { Fail to pay tax because of difficulty in bookkeeping or } \\
\text { poor record of revenue and expenditure cost }\end{array}$ & $0.066^{*}$ & $69 \%$ & $25 \%$ \\
\hline
\end{tabular}

* Correlation is significant at the 0.05 level (2-tailed)

The correlation analysis also shows that there is a negative correlation between non-tax compliance and business owners profit margin (0.024). There is a negative correlation between low education level (0.026) of small business owners and non-tax compliance in the country. Small business owners' failure to pay tax because of difficulty in bookkeeping or poor record of revenue and expenditure cost (0.066) shows a positive correlation with non-tax compliance. Some of the findings are consistent with the outcome of the research previously performed by Yesegat et al (2017), in respect of tax compliance problems in developing countries. The data analysis confirms the major reasons why small business owners in Nigeria do not comply with the tax laws of the country.

Table 5 address research question three which focused mainly on finding out what tax administrators felt was affecting their ability to effectively administer tax compliance laws in the country. The questionnaire was administered to 1,080 tax administrators at the federal and state governments levels in the country. Seventy-seven percent $(77 \%)$ of the respondents agree that federal and state governments are effectively enforcing tax compliance laws in the country while $23.15 \%$ disagree. Further $97.2 \%$ of the respondents indicated that the lack of appropriate assessment of business owners' profit and loss constitute sub-standard in the administration of tax policies in Nigeria. Ninety-one percent (91\%) of the respondents also acknowledge that lack of government incentives and poor working condition has affected the ability of tax administrators to work diligently in executing their functions. On one hand, 82\% of the tax administrators' respondents stated that poor communication between the tax office 
(federal and state governments) and citizens is another major issue affecting the enforcement of tax compliance laws in Nigeria. On the other hand, $81.6 \%$ of the respondents reported that inadequate number of tax inspectors to enforce the tax laws in the country has contributed to lower revenue generation of the government. In addition to the above tax administration problems $72 \%$ among the interviewed tax administrators alluded to the fact that corruption among some of their colleagues also negatively affects the administration of tax compliance laws in Nigeria.

Research Question 3: Do you believe that the Federal and State Governments in Nigeria are effective in the administration of tax compliance in the country?

Table 5. Perception of the Ability of Federal and State effective Taxes Administration in Nigeria

\begin{tabular}{|c|c|c|c|c|c|c|c|c|c|}
\hline No & Questions & $\begin{array}{c}\text { \# of } \\
\text { Strongly } \\
\text { Disagree }\end{array}$ & $\begin{array}{c}\text { \# of } \\
\text { Disagree }\end{array}$ & $\begin{array}{c}\text { \# of } \\
\text { Neutral }\end{array}$ & $\begin{array}{c}\text { \# of } \\
\text { Strongly } \\
\text { Agree }\end{array}$ & $\begin{array}{c}\text { \# of } \\
\text { Agree }\end{array}$ & $\begin{array}{c}\% \text { of } \\
\text { Disagree }\end{array}$ & $\begin{array}{c}\% \\
\text { Agree }\end{array}$ & $\begin{array}{l}\text { Total } \\
1,080\end{array}$ \\
\hline 29 & $\begin{array}{l}\text { Government is effectively } \\
\text { enforcing tax compliance }\end{array}$ & 150 & 100 & 0 & 602 & 228 & $\begin{array}{l}250 \\
23.15 \%\end{array}$ & $\begin{array}{l}830 \\
77 \%\end{array}$ & 1080 \\
\hline 30 & $\begin{array}{l}\text { Limited information about } \\
\text { tax regulation and many } \\
\text { citizens do not know the } \\
\text { tax laws in the country. }\end{array}$ & 124 & 75 & 23 & 340 & 518 & $\begin{array}{l}199 \\
18.14 \%\end{array}$ & $\begin{array}{l}794 \\
79.4 \% *\end{array}$ & 1080 \\
\hline 31 & $\begin{array}{l}\text { Corruption among some } \\
\text { tax administrators }\end{array}$ & 83 & 214 & 9 & 308 & 466 & $\begin{array}{l}297 \\
27.5 \% \\
\end{array}$ & $\begin{array}{l}774 \\
72 \% \\
\end{array}$ & 1080 \\
\hline 32 & $\begin{array}{l}\text { Inadequate number of tax } \\
\text { inspectors to enforce the } \\
\text { tax laws }\end{array}$ & 72 & 116 & 0 & 560 & 322 & $\begin{array}{l}188 \\
17.4 \%\end{array}$ & $\begin{array}{l}882 \\
81.6 \% *\end{array}$ & 1080 \\
\hline 33 & $\begin{array}{l}\text { Lack of government } \\
\text { incentives and poor } \\
\text { working condition }\end{array}$ & 60 & 40 & 0 & 720 & 260 & $\begin{array}{l}100 \\
9.25 \%\end{array}$ & $\begin{array}{l}980 \\
91 \% *\end{array}$ & 1080 \\
\hline 34 & $\begin{array}{l}\text { Weak relationship between } \\
\text { federal, state governments } \\
\text { and citizens }\end{array}$ & 90 & 210 & 0 & 504 & 276 & $\begin{array}{l}300 \\
27.2 \% \\
\end{array}$ & $\begin{array}{l}780 \\
72.2 \% \\
\end{array}$ & 1080 \\
\hline 35 & $\begin{array}{l}\text { Poor communication } \\
\text { between governments and } \\
\text { citizens }\end{array}$ & 127 & 68 & 7 & 274 & 611 & $\begin{array}{l}195 \\
18.1 \%\end{array}$ & $\begin{array}{l}885 \\
82 \%\end{array}$ & 1080 \\
\hline 36 & $\begin{array}{l}\text { Lack of appropriate } \\
\text { assessment of business } \\
\text { owners' profit and loss }\end{array}$ & 0 & 30 & 0 & 750 & 300 & $\begin{array}{l}30 \\
2.8 \% \\
\end{array}$ & $\begin{array}{l}1050 \\
97.2 \% *\end{array}$ & 1080 \\
\hline 37 & $\begin{array}{l}\text { Government negligence of } \\
\text { citizens leaving in rural } \\
\text { areas of Nigeria. }\end{array}$ & 100 & 116 & 70 & 428 & 366 & $\begin{array}{l}216 \\
20 \% \\
\end{array}$ & $\begin{array}{l}794 \\
73.5 \%\end{array}$ & 1080 \\
\hline 38 & $\begin{array}{l}\text { Our office use information } \\
\text { technology in tax } \\
\text { administration }\end{array}$ & 600 & 370 & 7 & 50 & 53 & $\begin{array}{l}970 \\
86 \% \\
\end{array}$ & $\begin{array}{l}103 \\
9.5 \% * \\
\end{array}$ & 1080 \\
\hline & Mean & & & & & & $25 \%$ & $73.6 \%$ & \\
\hline
\end{tabular}

Source: Derived from Field research in Nigeria in 2018 and 2019.

In addition, $79.4 \%$ of the tax administrators that completed the questionnaire confirmed that limited availability of information about tax regulation and the fact that many citizens do not know the tax laws is another issue that make them to believe that the administration of tax 
laws in the country is not effective. Two order very important issues that were also confirmed by tax administrators in Nigeria are (1) weak relationship between federal, state governments, and citizens (72.2\%); and (2) government negligence of citizens leaving in rural communities in the country. Despite the establishment of the Economic and Financial Crimes Commission (EFCC) law enforcement agency in Nigeria to investigate corruption as well as financial crimes among public administrators and political leaders $86 \%$ of the tax administrators indicated that there are some inspectors that are very corrupt. Furthermore, $86 \%$ of the tax administrators confirm that because staff are not provided with computers it is often difficult for them to conduct their job faster and accurately. It is interesting to note that although Nigeria has a democratic representative government, the political leaders tend to operate as if the country is still a military regime. This is really unfortunate to observe during our field research in the country. Political leaders still travel all over the country with military and police escort that constantly intimidate the citizens. The mean of table 3 data is: Agree $73.6 \%$ and Disagree $25 \%$ respectively.

An in-dept interview was conduct to 120 tax administrators at the federal and state government levels. Interview results shows that $75 \%$ of tax administrators confirm that many citizens in Nigeria have negative perception about the fairness and competence of tax inspectors. As a result of this perception $81 \%$ of the respondence believe that tax administrators do not accurately calculate citizens and small business organizations tax returns respectively. In addition, $85 \%$ of the interviewed respondents in the federal and state tax offices respectively indicated that tax compliance laws in Nigeria may not be perfect but it has had greater impact on companies and pay as you earn (PAYE) system all over the country.

Further $61 \%$ of the interview respondents indicated that there has been positive difference since 1999 when the military administration handed power to a democratic elected government. The tax administrators also contend that there are more people paying taxes now than what it used to be before 1999. Thus, the tax compliance laws has been revigorated because there was a greater attempt to enforce the laws despite some of the predicaments already discussed in this paper. Another $83 \%$ of the tax administrators interviewed also acknowledge that there are many small retailers in the country that do not pay taxes. It is also very difficult to ask people that are very poor to pay taxes when they live with less than \$US2 (two United States dollars a day). In addition 58\% of tax administrators' respondents indicated that many administrators often tend to disregard some aspects of the tax laws because they believe that some sections of the laws cannot be enforced to poor people in the country because of the relative tax compliance costs as a share of turnover in their business. 
Table 6. Correlation Matrix of effective in the administration of tax compliance

\begin{tabular}{|l|l|c|c|}
\hline Tax Compliance Factors & Index & $\begin{array}{l}\text { Average } \\
\text { Agree } \\
\text { Factors in \% }\end{array}$ & $\begin{array}{l}\text { Average } \\
\text { Disagree } \\
\text { Factors in \% }\end{array}$ \\
\hline Tax Policy Index & 0.051 & $73.6 \%$ & $25 \%$ \\
\hline $\begin{array}{l}\text { Lack of appropriate assessment of business owners' profit } \\
\text { and loss }\end{array}$ & $0.089^{* *}$ & $97.2 \%$ & $2.8 \%$ \\
\hline Lack of government incentives and poor working condition & $0.080^{* *}$ & $91 \%$ & $9.25 \%$ \\
\hline Our office use information technology in tax administration & 0.006 & $9.5 \%$ & $86 \%$ \\
\hline $\begin{array}{l}\text { Poor communication between federal and state governments } \\
\text { and citizens }\end{array}$ & $0.073^{* *}$ & $82 \%$ & $18.1 \%$ \\
\hline Inadequate number of tax inspectors to enforce the tax laws & $0.072^{* *}$ & $81.6 \%$ & $17.4 \%$ \\
\hline Corruption among some tax administrators & 0.050 & $72 \%$ & $27.5 \%$ \\
\hline
\end{tabular}

* Correlation is significant at the 0.05 level (2-tailed)

Table 6 show that there is a low negative correlation between office use of information technology in tax administration (0.006) and effective administration of tax compliance in Nigeria. In addition, the lack of appropriate assessment of business owners' profit and loss (0.089) has positive correlation with ineffective administration of tax compliance. Another very important area is the positive correlation between lack of government incentives and poor working condition (0.080) and ineffective administration of tax laws. Furthermore, poor communication between local governments and citizens (0.073) has a positive correlation with ineffective administration with tax compliance. It is very interesting to note that there is a positive correlation between inadequate number of tax inspectors to enforce the tax laws (0.072) and ineffective tax administration in Nigeria. Lastly, corruption has a moderate positive correlation (0.050) with ineffective tax administration in the country. The data analysis confirms the major reasons why tax administrators are not effectively administering tax compliance in Nigeria.

\section{Tax Administration Policy Recommendations}

What can the Federal Government of Nigeria do to establish new standards for evaluating its tax administration performance? The answer to this question will be the basis for the following tax administration policy recommendations. The major bone of contention for the Federal and State governments of Nigeria is to adopt measures that could help their senior administrators to better understand and improve their operational strategies. These new strategies must first define best practice, acceptable benchmark, and strategic tax administration outcomes. It will also be very helpful if the federal and state governments of Nigeria could allow a team of Nigerian private sector tax expert and some foreign consultants to help them assess the current tax administration practices in the country (Adekanola 1997; Agbadi 2011). This approach is considered to be more effective than requiring incumbent tax 
administrators to evaluate the current practice, as well as improve on their own performance. Bearing the fact that most administrators do not like to change their habits or management culture such approach could provide a negative outcome. According to Uzochukwu Alutu (2020) "the culture that citizens can decide not to pay taxes in exchange that the state cannot be held accountable for the ineffective delivery of public goods and services needs to change."

It is recommended that the Federal Government of Nigeria should explore a more pragmatic tax design method that could enhance or foster an equitable tax system for the citizen and all taxpayers in the country (Bird, 2013; Fagbemi \& Abogun 2014;). According to (Fjeldstad 2014) the best approach to achieve this new tax administration policy goal is to facilitate new information and communication technologies, adopt new taxpayer identification number; move from a universal or national approach to a model that is organized around different industrial size and states or localities. This new approach could help taxpayers in Nigeria to deal with only their regional tax administrators or inspectors. In addition, the new user-friendly benchmark approach could make the collection of taxes to be simplified (Zee et al 2002). It could also help the Federal Government of Nigeria to build more or wider trust with the citizens or taxpayers of the country. The new tax initiative could provide a fruitful avenue for further research on economic reform in Nigeria.

The Nigeria Government should adopt a benchmark tax administration system in order to improve on its current tax compliance system and operations. This new benchmark tax management approach could enable the government to allow local tax consultants and international agencies to collaborate to provide appropriate guidelines or objectives for appraisal of tax administration in the country (Vazquez-Caro \& Bird, 2011). This benchmark system of tax administration could also enable tax experts in the Nigeria to periodically collect appropriate data and analyze them to determine their compliance rate and other factors that could enable the government to improve on its tax administration functions (Alabede 2014; Fagbemi \& Abogun 2014). Furthermore, the introduction of continuing taxpayers' education in both urban and rural regions of each state in Nigeria by the federal and state governments could also galvanized more tax compliance, citizens' trust in government and awareness of tax laws.

The Federal Government of Nigeria should also consider a web-based e-filing system in the country. Moving towards a web-based tax administration system could enhance a speedy and a cost-effective process for filling tax in the country in the future. It is important to note that one of the latest methods and best practice of tax administration are electronic payment and e-filling systems (Vazquez-Catro \& Bird, 2011). The e-filling tax administration and electronic payment methods have also been identified as better methods for encouraging compliance and taxpayer service (Manaf et al 2010). Therefore, a tax administration system that promise cooperative compliance in order for taxpayers not to cheat or delay payment could generate more revenue than the current method that often facilitates corruption and lack of communication between taxpayers and tax administrators. It is recommended that for the federal and state governments of Nigeria to constantly use various technology platforms to educate the citizens on tax issues, as well as improve communication, to enhance citizen 
compliance. Table 7 shows the type of benchmark model that the federal and state governments in Nigeria should adopt in the future.

Table 7. Appropriate Benchmarking Model for Nigeria

\begin{tabular}{|c|c|c|}
\hline Benchmarks & Objectives & Result Indicators \\
\hline $\begin{array}{l}\text { - Tax Knowledge networking in } \\
\text { urban and rural societies all over } \\
\text { the country }\end{array}$ & $\begin{array}{l}\text { Forming a consensus for the basis of } \\
\text { interpreting and implementing tax } \\
\text { laws. }\end{array}$ & $\begin{array}{l}\text { Increased number of public, private } \\
\text { and civil society stake -holders' } \\
\text { meetings in the country }\end{array}$ \\
\hline $\begin{array}{l}\text { - Development of knowledge in } \\
\text { the in-land Revenue office }\end{array}$ & $\begin{array}{l}\text { Make knowledge and staff } \\
\text { development a priority in tax } \\
\text { administration all over the country }\end{array}$ & $\begin{array}{l}\text { More position impact on tax } \\
\text { administration performance and } \\
\text { incentives }\end{array}$ \\
\hline $\begin{array}{l}\text { - Technology information usage in } \\
\text { tax administration }\end{array}$ & $\begin{array}{l}\text { Provide all tax offices and staff } \\
\text { computers to perform their job } \\
\text { effectively. }\end{array}$ & $\begin{array}{l}\text { More use of technology platforms } \\
\text { to process tax and disseminate } \\
\text { information to citizens. }\end{array}$ \\
\hline - Tax Form information strategy & $\begin{array}{l}\text { Make tax administration rely } \\
\text { heavily on information provided by } \\
\text { the taxpayers }\end{array}$ & $\begin{array}{l}\text { More e-filling services, web-based } \\
\text { tax information and education of } \\
\text { citizens. }\end{array}$ \\
\hline - Client or citizens' focus & $\begin{array}{l}\text { Assess the priority given to clients } \\
\text { and the definition of service } \\
\text { standards }\end{array}$ & $\begin{array}{l}\text { Better and improved services to } \\
\text { clients and enforce standards }\end{array}$ \\
\hline $\begin{array}{l}\text { - Higher concern for equity than } \\
\text { maximization of tax collection }\end{array}$ & $\begin{array}{l}\text { Assess equity as a } \operatorname{tax} \\
\text { administration priority. }\end{array}$ & $\begin{array}{l}\text { Higher compliance and proper } \\
\text { collection levels }\end{array}$ \\
\hline $\begin{array}{l}\text { - Migration to web-based } \\
\text { interaction }\end{array}$ & $\begin{array}{l}\text { Assess web-based processes and } \\
\text { their impact to tax administration. }\end{array}$ & $\begin{array}{l}\text { Increased number of automated } \\
\text { transactions with internet access }\end{array}$ \\
\hline $\begin{array}{l}\text { - Basic internal control systems of } \\
\text { tax administration }\end{array}$ & $\begin{array}{l}\text { Assess the built-in-efficiency and } \\
\text { secure as well as update taxpayer } \\
\text { account system }\end{array}$ & $\begin{array}{l}\text { Efficient and accurate deterrence of } \\
\text { fraud and corruption }\end{array}$ \\
\hline
\end{tabular}

Source: Adopted from Vazquez-Caro, J. and Bird, R. M. (2011). Benchmarking Tax Administrations in Developing Countries: A Systemic Approach. Journal of Tax Research, Vol. 9, No. 1, pp. 28

Table 7 summarize a benchmark strategy that could be adopted my the federal and state government in-land revenue agencies to combat their current tax compliance predicaments. The strategy identified eight areas the Federal Government of Nigeria should focus on. The areas includes: (1) Tax knowledge networking in urban and rural societies all over the country; (2) Development of knowledge in the Internal Revenue office; (3) Technology information usage in tax administration; (4) Tax Form information strategy; (5) Client or citizens' focus; (6) Higher concern for equity than maximization of tax collection; (7) Migration to web-based interaction; and (8) Basic internal control systems of tax administration (Ezugwu et al 2014; Vazquez-Caro \& Bird 2011; Zee et al 2002). It should be noted however that benchmarking in not a simple process to adopt. Therefore, the Federal Government of Nigeria must be sincerely committed to enforce or implement all the 
mechanism for changing and improving on their current tax administration practices. According to Vazquez-Caro \& Bird (2011) and Yesegat et al (2017) the best approach for modernization or transformation of a tax administration system is to be clear about the new conceptual framework that is been adopted. It is very important to gather more information about the existing tax culture of the Nigeria Internal Revenue Agency as well as the degree of shared governance and empowerment of staff.

Furthermore, since the predicaments facing tax policy compliance in Nigeria reflects both administrative and political leadership failures in the country, there is an urgent need to educate the self-employed about tax policies in the country. One of the strategies to accomplish the above goals is the simplification of the current tax structure and the abolishment of some taxes. According to Fjeldstad (2014) and Bird 2013) developing countries having tax compliance problems should consider creating a more effective tax administration that could encourage a positive constructive citizens' engagement and better relationship of all stakeholders in the economic development. In most cases developing nations that have adopted a customer-service, user-friendly, and one-stop tax administration initiatives have been more successful (Alma 1992 et al; Flores-Macias 2018; Yesegat et al 2017; Fjeldstad 2014; Coolidge 2012).

\section{Conclusion}

This paper has examined the determinants of non-tax compliance among individuals, and business owners in Nigeria. It also explored some the impediments to tax administration in the Federal Government of Nigeria. Strategic benchmark and principal-agent models were explored in discussing tax compliance problems in Nigeria. Information asymmetric is very important for monitoring and modelling ethics in principal-agent contracts, and the activities of agents (tax administrators). It is also very important to promote ethical leadership in Nigeria. On the other hand, benchmark strategy initiative could help to develop cooperative system whereby taxpayers could have a legitimate right to expect something in return for taxes that they pay. This legitimate or constitutional right of the citizens or taxpayers could also enable them to hold the Federal Government of Nigeria and its political leaders and administrators accountable if they become more corrupt and ineffective in performing diligently.

The data analysis confirms the major reasons why individuals and small business owners in Nigeria do not comply with the tax laws of the country. The study also confirms the major reasons why tax administrators are not effectively administering tax compliance in Nigeria. It should be noted that some of the impediments to compliance identified are not necessarily the fault of the individuals and small business owners. Thus, the federal and state governments in Nigeria have to improve on their communication strategies with both the individuals, small business owners in the country. The utilization of modern technology and building more Inland Revenue (tax) offices in all local governments, as well as providing constant electricity supply are possible solutions to the identified tax compliance problems. The federal and state governments in Nigeria must also be mindful that the enforcement of compliance would require more tax inspectors in the country. New initiatives to stimulate 
economic development all over the Nigeria could also increase tax compliance in the country.

The finding of this research reveals that many citizens and business owners continue to advocate for lower taxes and cut in government spending in Nigeria. This ideology of citizens has several ramifications (1) citizens prefer that greater tax revenue in Nigeria should be sought not by imposing higher taxes but through the expansion of taxable economic activities; (2 ) public administrators and political leaders in Nigeria are not trustworthy; (3) political leaders and public administrators were wasting government funds instead of using it to provide public good and services; (4) federal and state governments powers should be reduced because smaller, decentralized government was the best. Therefore, a good tax system for Nigeria should be designed to reflect the moral values of equality, truthfulness, honesty, contempt and the maximization of liberty for all citizens to equitably enjoy the goods and services that their resources have been used to provide by their elected government officials.

Tax policies and administration in Nigeria are not neutral and technical choice but the embodiments of citizens and ethical leaders as well as the promotion of economic development programs. The federal and state governments of Nigeria should establish simple and predictable tax systems that will not discourage private business owners' operation as well as minimize interference with market trends in the country.

Future research should investigate how the Federal Government of Nigeria could better encourage citizens in the rural areas in the country to build trust and comply with the tax laws. It is very important for the Federal Government of Nigeria to constantly use various technology platforms to educate the citizens on tax issues, as well as improve communication, to enhance citizen compliance. Therefore, a more detailed and pragmatic benchmark approach as well as customer service, and user-friendly, and one-stop strategies might help to facilitate a better tax administration initiative in Nigeria in the near future.

\section{References}

Adekanola, O. (1997). Efficient tax collection and effective tax administration in Nigeria. Paper presented at a seminar organized by the university of Lagos consultancy services Otta, (May) 15.

African Development Bank (2011). Domestic resource mobilization for poverty reduction in East Africa: lesson for tax policy and administration. The knowledge and information center (KVRC), African Development Bank: Tunis.

Agbadi, S. B. (2011). Determinants of tax compliance: A case Study of VAT flat rates scheme traders in the Accra Ghana metropolis. A thesis submitted to the institute of distant learning Kwame Nkrumah University of Science and Technology, Kumasi.

Alabede, O. J. (2014). An exploratory analysis of individual taxpayers' compliance behavior in Nigeria: A study of demographic differences and impact. International journal of accounting and taxation, 2(2), 39-64.

Alm, J., McClelland, G., \& Schulze, W. (1992). Why Do People Pay Taxes? Journal of 
Public Economics, 48, 21-38. https://doi.org/10.1016/0047-2727(92)90040-M

Alutu, U. U. (2020). The African report: The Nigeria focus. Retrieved from www.webscribe. co.uk /magazine/theafrica report. January 7, 2020.

Badara, M. S. (2012). The effect of tax audit on tax compliance in Nigeria: A study of Bauchi State Board of internal revenue. Journal of Finance and Accounting, 3(4), 12 - 31.

Baer, K., Benon, O., \& Toro, J. R. (2002). Improving large taxpayers' compliance: A review of country experience. Washington DC: International Monetary Fund. https://doi.org/10.5089/9781589061187.084

Bhatia, H. L. (2009). Public finance. New Delhi: Vikas Publishing House, PVT Limited.

Bird, R. (2012). Taxation and development: What have we learned from fifty years of research? ICTD Working Paper \#1 (pp. 1-16) International Center for Tax and Development.

Bird, R. (2013). Foreign advice and tax policy in developing countries. International Center for Public Policy working paper (pp.13-27, April). Georgia State University, Andrew Young School of Policy Studies: Altanta.

Bird, R., \& Banta, S. (2000). Fiscal sustainability and fiscal indicators in transitional countries. In A. Shapleigh, F. Andic. \& S. Banta. (Ed.). Transition economics and fiscal reforms. Proceedings of the conference on central and eastern Europe and the new independent states, Istanbul, (July 1999, pp. 13-42). Washington: USAID. https://doi.org/10.2139/ssrn.2437489

Bohren, O. (1998). The agent's ethics in the principal agent model. Journal of Business Ethics, 17, 745-755. https://doi.org/10.1023/A:1005722800141

Braithwaite, V. (2003) A new approach to tax compliance.” In A. Braithwaite (ed.) taxing democracy: understanding tax avoidance and evasion. Aldershot United Kingdom: Ashgate Press.

Brautigram, D., Fjeldstad O., \& Moore, M. (2008). Taxation and state building in developing countries: Capacity and consent. Cambridge UK: Cambridge University Press. https://doi.org/10.1017/CBO9780511490897

Carter, A., \& Cebreiro, A. (2011). Africa's tax system: A survey OECD observer: OECD center for tax policy and administration; 284

Coolidge, J. (2012). Findings of tax compliance cost surveys in developing countries. E-Journal of Tax Research, 10(2), 250-287

Corgnet, B., Gómez-Miñambres, J., \& Hernán-González, R. (2018). Goal setting in the principal-agent model: Weak incentives for strong performance. Economic science institute at Chapman University. Retrieved from https://digitalcommons.chapman.edu/esi_pubs/, January 13, 2020. https://doi.org/10.1016/j.geb.2017.12.017

Das-Gupta, A. (2002). Central tax and administration reform in the 1990s: An assessment. In 
R. Govinda (ed.). Development, poverty, and fiscal policy. New Delhi: Oxford University Press, 139-173.

Dibie, R. (2018). Business and government relations in Africa. New York: Routledge. Taylor \& Francis Press. https://doi.org/10.4324/9781315204987

Ezugwu, C. I., \& Agbaji, J. (2014). Assessment of the application of taxpayer identification number on internal generated revenue in Kogi State Nigeria. Mediterranean Journal of Social Science, 5(20), 38-48. https://doi.org/10.5901/mjss.2014.v5n20p38

Fagbemi, T. O., \& Abogun, S. (2014) Factors influencing voluntary tax compliance of small and medium scale enterprises in Kwara State Nigeria. Entrepreneurial Journal of Management Science, 32(1), 98-127.

Fjeldstad, O. (2014). Tax and development: Donor support to strengthen tax system in developing countries. Public Administration and Development, 34(1), 181-192. https://doi.org/10.1002/pad.1676

Fjeldstad, O., \& Moore, M. (2009). Revenue authorities and public authority in Sub-Saharan Africa. The Journal of Modern African Studies, 47(1), 1-18. https://doi.org/10.1017/S0022278X08003637

Flores-Macis, G. A. (2018). Building support for taxation in developing countries: Evidence from Mexico. World Development, 105(1), 13-24. https://doi.org/10.1016/j.worlddev.2017.12.014

Foluso, F. (2013). Nigeria tax companion. Lagos: Hortosaf Associates Ltd Press.

Groenendijk, N. (1997). A principal-agent model of corruption. Crime, Law and Social Change, 27(1), 229-229. https://doi.org/10.1023/A:1008267601329

Gruber, J. (2019). Public finance and public policy. (5 ${ }^{\text {th }}$ ed.). New York: Worth Publishers.

Jansen, M., \& Meckling, W. (1976). Theory of the firm: Managerial behavior, agency costs, and ownership structure." Journal of Financial Economics, 3(1), 305-360. https://doi.org/10.1016/0304-405X(76)90026-X

Jibao, S., \& Prichard, W. (2015). The political economy of property tax in Africa: Explaining reform outcomes in Sierra Leone. African Affairs, 114(456), 404-431. https://doi.org/10.1093/afraf/adv022

Kiabel, D. B., \& Nwokah, G. N. (2009) Boosting revenue generation by state governments in Nigeria: The tax consultant option revisited. European Journal of Sciences, 8(4), 17-36.

Lieberman, E. S. (2003). Race and regionalism in the politics of taxation in Brazil and South Africa. Cambridge United Kingdom: Cambridge University Press. https://doi.org/10.1017/CBO9780511615658

Lymer, A., \& Oats, L. (2009). Taxation: policy and practice. (16th ed.) Birmingham, England: Fiscal Publications. 
Mahon, J. Jr. (2012). Tax incidence and tax reforms in Latin America. "Washington, DC: Woodrow Wilson Center Paper.

Manaf, N. A. A., Ishak, Z., \& Sarayu, A. (2010). The acceptance of e-filling among individual taxpayer. Paper presented in the international tax administration conference (7-9, April) in Sydney, Australia.

Mkandawire, T. (2010). On tax efforts and colonial heritage in Africa. Journal of Development Studies, 46(10), 1647-1669. https://doi.org/10.1080/00220388.2010.500660

Moore, M. (2008). Between coercion and contract: Competing narratives around taxation and governance. In D. Brautigram, Fjeldstad, O. \& Moore M. (ed., pp. 23-50). Taxation and state building in developing countries: Capacity and consent. Cambridge UK: Cambridge University Press. https://doi.org/10.1017/CBO9780511490897.002

Okaura, I. O. (2012). A comprehensive tax history of Nigeria. Ibadan: In I. O. Okauaru (ed, pp.1-27) Ibadan, Nigeria: Safari Books Ltd.

Ola, C. S. (2001). Income tax law and practice in Nigeria. Ibadan, Nigeria: Heinemann Educational Books Plc.

Ondetti, G. (2015). The roots of Brazil's heavy taxation. Journal of Latin American Studies. 47(3), 749-779. https://doi.org/10.1017/S0022216X15000796

Organization for Economic Cooperation and Development (OECD) (2012). Tax and development: aid modalities for strengthening tax system (August). Paris OECD Press.

Pinhanez, M. (2008). Reinventing VAT collection: industry vertical assessment, revenue increase, and public sector reliability, Ph.D. thesis, Boston: Massachusetts Institute of Technology.

Prichard, W. (2015). Taxation, accountability, and responsiveness in Sub-Saharan Africa: The Dynamics of tax bargaining. New York: Cambridge University Press. https://doi.org/10.1017/CBO9781316275511

Quinn, D., \& Jones, T. (1995). An agent morality view of business policy. Academy of Management Review, 20(1), 22-42. https://doi.org/10.5465/amr.1995.9503271989

Schiller, A. V. (2018). Party system institutionalization and reliance on personal income taxation in developing countries. Journal of International Development, 30(1), 274-301. https://doi.org/10.1002/jid.3347

Schneider, A. (2012). State building and tax regime in Central America. New York: Cambridge University Press. https://doi.org/10.1017/CBO9781139094061

Seljan, E. (2014). The limits of tax and expenditure limits: TEL implementation as a principal-agent problem. Public Choice, 259(1), 485-501. https://doi.org/10.1007/s11127-013-0063-0 


\section{Macrothink}

Journal of Public Administration and Governance ISSN 2161-7104 2020, Vol. 10, No. 2

Shanmugan, S. (2003). Managing self-assessment and appraisal of tax. National First Quarter, 1(1), 30-32.

Stewart, M. (2003). Global trajectories of tax reform: Mapping tax in developing and transition countries. Harvard International Law Journal, 44(1), 140-190. https://doi.org/10.2139/ssrn.319200

Tanzi, V., \& Zee, H. H. (2000). Tax policy for emerging markets: Developing countries. International Monetary Fund working paper WP/00/35. Washington DC: International Monetary Fund. https://doi.org/10.5089/9781451845341.001

Usman, S. (2008). Tax compliance in Nigeria. Federal Polytechnic Jigawa, Accounting Journal, 21-28.

Vazquez-Caro, J., \& Bird, R. M. (2011). Benchmarking tax administrations in developing countries: a systemic approach. Journal of Tax Research, 9(1), 5-37.

Von-Soest, C. (2008). Donor support for tax administration reform in Africa: Experience from Ghana, Tanzania, Uganda, and Zambia. German Development Institute Discussion Paper 2, Bonn: German Development Institute.

Weingast, B. (1984). The congressional-bureaucratic system: A principal-agent perspective. Public Choice, 44(1), 147-192. https://doi.org/10.1007/BF00124821

Yesegat, W. A., Coolidge, J., \& Corthay L. O. (2017). Tax compliance costs in developing countries: evidence from Ethiopia. Journal of Tax Research, 15(1), 77-104.

Zee, H., Stotsky, J., \& Levy, E. (2002). Tax incentives for investment: A primer for policy makers in developing countries. World Development, 30(1), 1497-1516. https://doi.org/10.1016/S0305-750X(02)00050-5

\section{Copyright Disclaimer}

Copyright for this article is retained by the author(s), with first publication rights granted to the journal.

This is an open-access article distributed under the terms and conditions of the Creative Commons Attribution license (http://creativecommons.org/licenses/by/4.0/). 